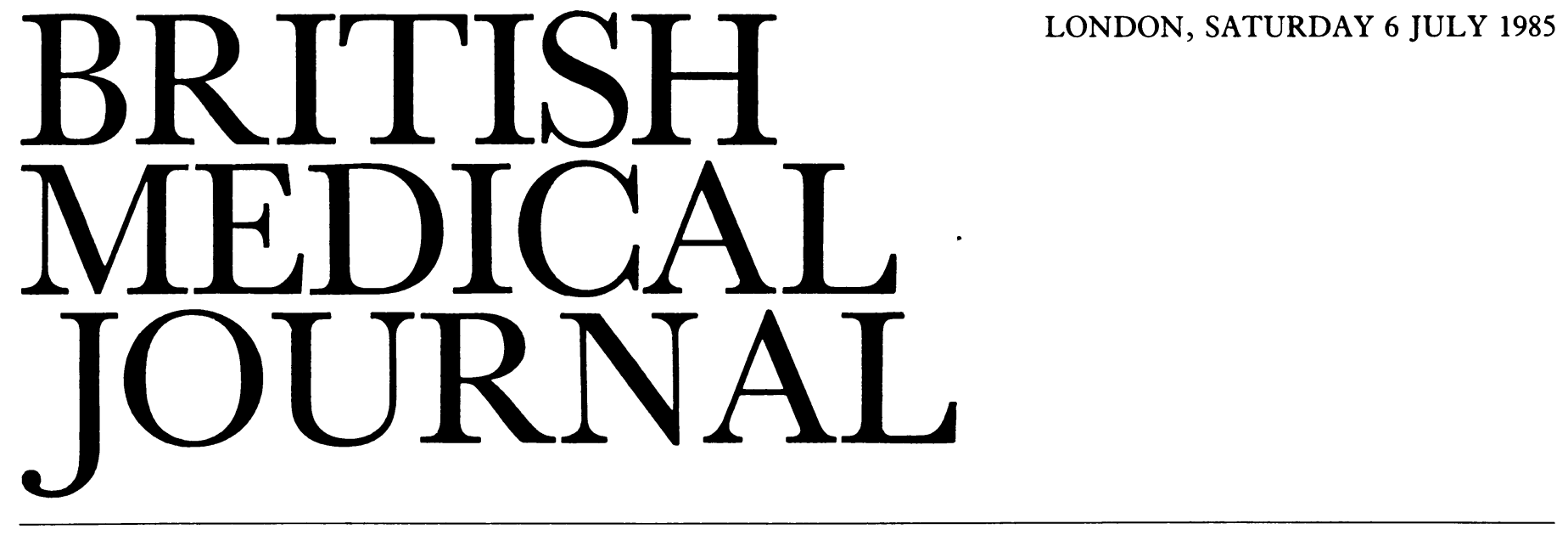

\section{What's new about hay fever?}

Since Charles Blackley first described the association of nasal symptoms of sneezing, rhinorrhoea, and obstruction with seasonal changes in the pollen count ${ }^{1}$ our understanding of the pathophysiology of hay fever, seasonal allergic rhinitis, or pollenosis has steadily increased. Pollenosis is one of the best clinical examples of the type I or immediate hypersensitivity reaction. Soluble allergens derived from the pollen grains of trees, shrubs, grasses, and flowers can stimulate both the systemic and mucosal synthesis of specific reaginic antibodies. ${ }^{23}$ Inımunoglobulin $\mathrm{E}$ binds (through the $\mathrm{C} 4$ domain of its $\mathrm{H}$ chains) with high affinity to $\mathrm{Fc}$ receptors on the surface of mast cells and basophils. The mast cells are activated to secrete mediators by a mechanism that depends on cross linkage of the bound IgE antibodies by specific allergens. ${ }^{4}$ Thus experimental nasal provocation with appropriate allergens induces gross degranulation of mast cells both on the mucosal surface and in the submucosa. ${ }^{5}$

Nasal challenge causes the release of a whole range of chemical mediators, and these may readily account for many of the symptoms of pollenosis. The activation of mast cells by IgE leads to the release of preformed mediators including histamine, exoglycosidases, the neutral protease tryptase, and eosinophil and neutrophil chemotactic factors; it also stimulates the generation and release of newly formed mediators, including prostaglandin $\mathrm{D}_{2}$ and the 5 lipoxygenase products leucotrienes $\mathrm{C}_{4}$ and $\mathrm{D}_{4}$ that together were previously recognised as slow reacting substance of anaphylaxis. ${ }^{6}$ Histamine causes both direct and reflex dilatation of postcapillary venules, leading to nasal obstruction; stimulates irritant receptors causing sneezing; and stimulates secretion from goblet cells and submucosal glands. ${ }^{7}$ Exoglycosidases such as $\beta$ glucuronidase, $\beta$ hexosaminidase, $\beta$ galactosidase, and arylsulphatase together with neutral proteases disrupt the integrity of the mucous membrane through their specific actions on tissue ground substance. Prostaglandin $\mathrm{D}_{2}$ is a potent vasodilator, causing vascular engorgement of the mucosa, while leucotriene $\mathrm{C}_{4}$ increases capillary permeability, causing exudation. ${ }^{8}$ The interaction of these mediators might be expected to cause oedema of the mucous membrane and nasal obstruction. Chemotactic recruitment of secondary effector cells such as eosinophils, neutrophils, and basophils to the sites of mast cell degranulation, together with their activation, releases further mediators to compound the inflammatory response which leads to a state of chronic nasal hyperreactivity.

(C) BRITISH MEDICAL JOURNAL 1985. All reproduction rights reserved.
In patients with allergic rhinitis provocation by allergens evokes both early and late reactions characterised by the release of inflammatory mediators detectable in nasal lavage fluid. Prostaglandin $\mathrm{D}_{2}$ and leucotrienes $\mathrm{C}_{4}$ and $\mathrm{B}_{4}$ are released during the early reaction in parallel with histamine and a proteolytic THAME esterase activity capable of generating bradykinin. ${ }^{9-12}$ Histamine, leucotriene $\mathrm{C}_{4}$, and THAME esterase are also generated during the late reaction, but the absence of prostaglandin $\mathrm{D}_{2}$ (whose release is specific for mast cells ${ }^{13}$ ) suggests that basophils rather than mast cells are responsible for the secretion of mediators at this time. ${ }^{14}$ Cytological examination of nasal and conjunctival secretions of patients with active pollenosis shows many basophils and eosinophils-presumably recruited by the release of chemotactic factors derived from mast cells, such as leucotriene $B_{4}$.

Mast cells are found in large numbers in the mucous membranes of the nose and conjunctivae. ${ }^{15}{ }^{16}$ In genetically susceptible atopic patients exposure to high concentrations of aeroallergens not only leads to the active sensitisation of mast cells but also increases their numbers in the mucosa of the respiratory tract. ${ }^{17}$ Studies in rodents have recently drawn attention to two subpopulations of mast cells located in the mucosa and connective tissue; these have different morphological, histochemical, functional, and pharmacological characteristics. Infestation of rats with the intestinal parasite Nippostrongylus brasiliensis induces an up to 10 -fold increase in the number of mast cells in the gastrointestinal mucosa. ${ }^{18}$ These "mucosal mast cells" are smaller and have secretory lysosomal granules that contain a different neutral protease (RMCP-II) from the classic "connective tissue mast cells" that contain chymase (RMCP-I). ${ }^{19}$ The granule proteoglycan of mucosal mast cells also differs from classical heparin in containing glycosaminoglycan chains which are less sulphated (chondroitin sulphate di-B). ${ }^{20}$ Though the main neutral protease of human connective tissue mast cells has been identified as tryptase ${ }^{21}$ and the proteoglycan as a smaller molecular weight species of heparin, ${ }^{22}$ it is not known whether human mucosal mast cells exhibit a similar form of heterogeneity to that described in rodents.

The antigen induced hyperplasia of rodent mucosal mast cells results from the generation of a specific glycoprotein lymphokine of molecular weight 20000 daltons termed interleukin $3 .^{23}$ In the presence of interleukin 3 mucosal type mast cells may be grown in tissue culture from mouse bone 
marrow. ${ }^{24}$ Possibly in pollinosis seasonal exposure to high concentrations of environmental allergens induces a similar form of $\mathrm{T}$ cell dependent mast cell hyperplasia; and this may contribute in some way to the rapid seasonal deterioration of symptoms.

STEPHEN T Holgate

Reader in medicine and honorary consultant physician

Peter H Howarth Lecturer in medicine

University of Southampton,

Southampton General Hospital,

Southampton SO9 4XY

1 Blackley CH. Experimental researches on the causes and nature of catarrhus aestivus (hay fever or hay asthma). London: Baillière, Tindall and Cox, 1873.

2 Yunginger JW, Gleich GJ. Seasonal changes in serum and nasal IgE concentrations. $\mathcal{F}$ Allengy Clin Immunol 1973;51:174-9.

3 Merrett TG, Hovri M, Mayer ALR, Merrett J. Measurement of specific IgE antibodies in nasal secretions-evidence for local production. Clin Allengy 1976;6:69-73.

4 Ishizaka T, Ishizaka K. Activation of mast cells for mediator release through IgE receptors. In: Ishizaka K, ed. Mast cell activation and mediator release. Pregress in allergy. Vol 34. New York: Karger, 1984.

5 Corrado OJ, Gomez E, Davies TJ. Nasal mast cells: characteristics and effect of allergen. $f$ Allergy Clin Immunol 1985; 75(suppl): 153 .

6 Holgate ST, Robinson C. Mast cell-dependent inflammatory mediators and their putative role in bronchial asthma. Clin Sci 1985;68:103-12.

Mygind N. Mediators of nasal allergy. F Allergy Clin I mmunol 1982;70:149-59.

8 Lewis RA, Austen KF. Mediators of local homeostasis and inflammation by leukotrienes and other mast cell dependent compounds. Nature 1981;293:103-8.

Naclerio RM, Meier HL, Adkinson NF Jr, et al. In vivo demonstration of inflammatory mediator release following nasal challenge with antigen. Eur $\mathcal{F}$ Respir $D$ is 1983;64(suppl 128):26-32.

10 Creticos PS, Peters SP, Adkinson NF, et al. Peptide leukotriene release after antigen challenge in patients sensitive to ragweed. $N$ Engl f Med 1984;310:1626-30.

11 Shaw RJ, Fitzharris P, Cromwell O, Wardlaw AJ, Kay AB. Allergen-induced release of sulphidopeptide leukotrienes (SRS-A) and $\mathrm{LTB}_{4}$ in allergic rhinitis. Allergy 1985;40:1-6.

12 Proud D, Togius A, Naclerio RM, Crush SA, Norman PS, Lichtenstein LM. Kinins are generated in vivo following nasal airway challenge of allergic individuals with allergen. $\mathcal{J} \mathrm{Clin}$ Invest 1983;72:1678-85.

13 Holgate ST, Burns GB, Robinson C, Church MK. Anaphylactic- and calcium-dependent generation of prostaglandin $\mathrm{D}_{2}\left(\mathrm{PGD}_{2}\right)$, thromboxane $\mathrm{B}_{2}$, and other cyclooxygenase products of generation of prostaglandin $\mathrm{D}_{2}\left(\mathrm{PGD}_{2}\right)$, thromboxane $\mathrm{B}_{2}$, and other cyclooxygenase products of 1984;133:2138-44.

14 Norman PS, Naclerio PS, Creticos A, Togias A, Lichtenstein LM. Mediator release after allergic and physical nasal challenges. Proceedings of CIA meeting, Mexico 1984. Int Arch Allergy Appl Immunol (in press).

15 Okuda M, Ohtsuka S, Kawabori S. Basophil leukocytes and mast cells in the nose. Eur $\mathcal{J}$ Respir Dis 1983;64(suppl 128):7-14.

16 Flint KC, Hudspith BN, Leung KBP, Pearce FL, Brostoff J, Johnson McIN. Bronchoalveolar mast cells in extrinsic asthma. Clin Sci 1985;68(suppl):33P.

17 Otsuka H, Denburg J, Dolovich J, et al. Human nasal metachromatic cell (HNMC) heterogeneity: relation to clinical status and response to beclomethasone dipropionate. $f$ Allengy Clin Immunol $1985 ; 75$ (suppl): 153

18 Woodbury RG, Miller HRP. Quantitative analysis of mucosal mast cell protease in the intestine of nippostrongylus-infected rats. Immunology 1982;46:487-95.

19 nippostrongylus-infected rats. I mmunology 1982;46:487-95. Methods Enzymol 1981;80:588-609. 20 Stevens R, Austen KF. Proteoglycans of mast cells. In: Befus D, Bienenstock J, Denbury JA, eds. Mast cell heterogeneity. New York: Academic Press (in press).

Mast cell heterogeneity. New York: Academic Press (in press).
Schwartz LB, Austen KF. Tryptase from human pulmonary mast cells: purification and Schwartz LB, Austen KF. Tryptase from human
characterization. $\mathcal{F}$ Biol Chem 1981;256:11939-43.

22 Metcalf DD, Lewis RA, Silbert JE, Rosenberg RW, Wasserman SI, Austen KF. Isolation and characterization of heparin from human lung. F Clin Invest 1979;64:1537-42.

23 Ihle JN, Keller J, Oroszlan S, et al. Biologic properties of homogeneous interleukin 3. $f$ Immunol 1983;131:282-7.

24 Razin E, Ihle JN, Seldin D, et al. Interleukin 3: a differentiation and growth factor for the mouse mast cell that contains chondroitin sulfate E proteoglycan. F I mmunol 1984;132:1479-86.

\section{Epilepsy and employment}

The idea of possession by demons as the cause of epilepsy disappeared two centuries ago, but sufferers still have to contend with irrational prejudices in society - as well as with justified fears and problems. ${ }^{1}$ In the world of work the combination of real and imaginary barriers may be overwhelming. Recently a conference on epilepsy and employment organised by Labaz - the third it has held on epilepsy -looked at the problems.

Evidence abounds of the difficulties epileptics may have in getting and keeping jobs when their condition is known; between a quarter and three quarters have been found to experience work problems, including having poor jobs. ${ }^{1}$ The conference heard about often unnecessary restrictive and insensitive approaches_even within the NHS. Three separate aspects must be distinguished: the hazards posed by some jobs (to the sufferer or to others) where there is any chance of a seizure at work; where there is no hazard, anxiety and prejudice on the part of employers and fellow workers; and problems other than seizures, such as behavioural and mental abnormalities, that may be associated with the epilepsy or an underlying condition and be the real source of trouble.

The work capacity, including the accident and sickness rates, of those who have epilepsy uncomplicated by other problems is good. ${ }^{1-4}$ The combination of frequent seizures and low social class does, however, make unemployment much more likely. ${ }^{5}$ In a case-control study carried out in the steel industry and reported to the conference by D J Dick, about half of the 45 patients had at least moderate epilepsy and one third had changed their job because of their condition; but in most comparisons of work performance and other features they did not differ significantly from the controls and overall fared adequately in this heavy industry.

As the myth is exploded of the poor work record associated with epilepsy so should prejudice be further dispelled, making concealment less of a temptation to people with epilepsy. As it is, about half are said to conceal their condition (in one study only four of 40 patients had always disclosed $i^{5}$ ), and some doctors apparently do not discourage this. But honesty is the best policy, several speakers emphasised. Concealment may occur even with high risk jobs such as driving; an example quoted was a young bus driver who was discovered to have suffered from epilepsy for 12 years only after killing a motorcyclist during a fit; a medical certificate from someone other than an applicant's own doctor should arouse suspicion. ${ }^{6}$ But in general people fear, often rightly, that their job applications will not be considered on their merits if they admit a history of epilepsy-and moreover that their medical history will not be assessed by anyone knowledgeable. M Espir suggested that employers should follow the Civil Service practice of keeping the medical declaration form separate from the application form, to be looked at only when the candidate's merits have been decided, and that someone should be rejected on medical grounds only after a medical examination.

Behaviour problems cause the most concern in epilepsy, and the element of unpredictability worries employers and fellow workers alike. In addition, there may be cognitive impairment as a result either of disease or of drug treatment. Proposing guidelines on the psychological aspects, E G Lucas emphasised that medical examination of epileptics must cover mental functioning, especially concentration and short term memory. The occupational physician or nurse must also look at stress, so that early intervention and support may be possible-when it is known what circumstances appear to increase seizures. Thus psychological management of epilepsy at the workplace should focus, said Dr Lucas, on making time to understand the individual's total circumstances including those at home; finding out his attitudes; learning about his assets, motivation for work, and relationships with colleagues; and giving advice to the management.

Plenty of practical suggestions came up at the conference for making the best practices more widespread. They centred on removing unnecessary restrictions and providing detailed guidance on the types of work that individuals might do (the National Coal Board's guidelines recommend written instructions to personnel), with careful monitoring and management at the workplace-including initial and continuing 